\title{
Managing Teacher Educator to Improve Professional Teacher
}

\author{
Udik Budi Wibowo \\ Education Management \\ Universitas Negeri Yogyakarta, Indonesia \\ udik_bw@uny.ac.id
}

\author{
Arum Dwi Hastutiningsih \\ Education Management \\ Universitas Negeri Yogyakarta, Indonesia \\ adhinsm3t@gmail.com
}

\begin{abstract}
The success of professional teacher preparation depends on teacher educator management so this study aims to describe teacher educator management in the teacher profession education program. This research mainly uses the narrative inquiry method, and the data were analyzed through inductive interactive model. The study finds that the university management level implemented the general rules, which is made by ministry of education and culture. The implementations are choosing the teacher educators, socializing the curriculum of the program to the teacher educator and evaluating the program. The research found that there are some additional requirements in selecting teacher educator. Based on the result, this paper proposes to make specific evaluation in teacher educator management, and significant improvements in order to avoid collides schedule between the program and the regular classes.
\end{abstract}

Keywords - teacher profession program, teacher educator management

\section{INTRODUCTION}

Professional development program on teacher is not only being national issue but also international issue, cause teachers has strategic role to educate the next generation or excellent citizen of the nation. So, preparing professional teacher is determining the future of nation destiny.

Many strategies were applied to get the best achievement on the program. One of them is Program Pendidikan Profesi Guru (PPG) or Teacher Profession Education Program (TPEP). The program consisted of two components designed to provide academic, practical, and professional development. These included one semester of theoretical study in the university, which included the presentation of case studies, and Subject Specific Pedagogy workshop, and one semester for an internship program for teacher candidate.

All of the one-year-program was design using the implementation of personal management principles, which include planning, organizing, actuating and controlling. These principles are the important function to manage the program on the right track. However, it is not easy to manage the program that conducted together with full agenda of regular class. Then, the research question is how the performance of the teacher profession education program (TPEP)?

\section{LITERATURE REVIEW}

Teacher education is considered to be the first and perhaps the most important stage in the professional development of student teachers[1]. Meanwhile professional education must be education for professional practice if it is to be either professionally responsible or usable[2]. So, teacher professional education program should be improved the knowledge, skills, and values that will enable teacher candidates to be highly effective in helping student to learn.

Professional can be defined as a trained and qualified specialist who displays a high standard of competent conduct in their practice.[3] Professional development of teacher educators shifts the focus from teaching to a more productive emphasis on learning and some genres were found; managing understanding, advisory talk and meta-analytic talk.[4] The developing on teacher educator is important because teacher educators also have a variety of tasks and should teach a subject or pedagogy, and support students who do field work.[5] The professional development program is used to support teacher educators. This is so important just because lack of support is related to their practice assessment, commitment to work and to the need for innovative changes[6].

The research focus on the impact of language teacher educators' ideas and beliefs with regard to Teaching English as a Foreign Language (TEFL) and their teaching practices on their student teachers' beliefs and perceptions about their role as a language teacher. This study showed that similarities were found between student teachers and their teacher educators in terms of their ideas and beliefs about language teaching[7].

The result showed that the study was the first series designed to educate understanding of teacher educators' purposes for professional experience, reinforces the importance of professional experience as authentic workplace learning within initial teacher education[8]. The findings reveal that underpin teacher educators' practices when preparing, monitoring and supervising preserve teachers for and within the professional experience[9]. 
The research stated that the crucial role of initial teacher education programs and teacher educators in preparing effective inclusive practitioners has been universally acknowledged. The study found positive attitudes and considerable support for inclusive education. However, the majority of teacher educators were of the view that it was inadequately prepared for the implementation of inclusive education [10].

\section{RESULTS AND DISCUSSION}

This research mainly uses the narrative inquiry method with the deep interview, observation and document review. The study focuses on implementation of personal management principals to improve the teacher educator professional capacity. Data were analyzed through an inductive interactive model. Universitas Negeri Yogyakarta was chosen as a place in the study because the university got the highest number of graduation student. The findings of the interview are presented based on these groups. The discussion is following in each section.

\section{A. Planning}

At the stage of planning human resources in particular teachers, the process refers to the manual assignment of Teacher Profession Education Program obtained from the Ministry of Education and Culture (MoEC). In the planning process, roles and responsibilities, the implementation of TPEP is divided into 3 levels, i.e.

1. University Management acts as policy makers, organizers, and facilitators.

2. Faculty Management acts as a mediator, coordinator, and facilitator.

3. Department management acts as the leading implementation of TPEP executor. In the majors, the department/lecturer will be mobilized and coordinated for concerning the TPEP. The department will discuss and assign the associated qualified lecturers to become an instructor in the TPEP.

In the planning, there are a number of steps before it comes to socialization. The processes are:

a. Find out qualifications for teacher educators and the amount needed for TPEP based on the ratio of lecturers and students. Qualifications of the instructor manual are arranged in TPEP Handbook. The qualifications are:

(1) Has master's degree or doctorate that is both or one of them based on education, preferably having the certificate of expertise,

(2) Has Lector (senior lecturer) functional position,

(3) Has the ability to set, implement, and evaluate teaching learning process, and able to do nurturing, and

(4) Capable of performing supervision and provide feedback to students with andragogy.

b. Identify the existing resources (selected qualified)
Once the requirements are obtained, and then the Department determines and gives the assignment against the lecturer to become TPEP instructors. The assignment is done in the department based on the quality assurance standard of the lecturer i.e.:

(1) Recruitment and appointment of teaching staff have a minimum level of competency standards.

(2) The instructor should be given the opportunity to develop and expand the ability of teaching.

(3) Gives the opportunity to the less competent lecturers to enhance skills.

c. Appoint the teacher educator to be an instructor for TPEP. After making decision, then the department proposed/ submit a list of the teacher educator who will be instructor to Lembaga Pengembangan dan Penjaminan Mutu Pendidikan (LPPMP) Universitas Negeri Yogyakarta*.

\section{d. Provisioning for TPEP.}

After LPPMP acquired the definitive teacher educators who will be the instructor, LPPMP invited them to participate in the provisioning of TPEP. At this stage, the teacher educators not only get a briefing on developing syllabus of teaching learning process of TPEP, but also the duties and responsibilities of instructors.

The study indicates there are some additional nonprofessional requirements to appoint teacher educators. It happens because of their activities so they are not easy to be contacted. This is a reason for department to choose teacher educators who can be contacted easily.

\section{B. Organizing}

At the second stage, namely organizing, majors commissioned one to become coordinator of the department. Coordinator gives task to teacher educator as coaching team for workshops and internship. For workshop, one team consists of 2-3 instructors, consisting of one or two related science professor, and one of the professors of science education. For internship, one lecturer/subjects accompany one school.

With all teacher educators' background, teacher candidates could develop subject specific pedagogy based on the student needs. The problem is the teacher educators not only teach at TPEP but they teach regular classes also. In some cases, teacher educator should leave their general schedule in regular classes to attend TPEP classes.

\section{Actuating}

In the implementation of personal management, teacher educator divides into two parts namely workshop team and internship team, with the proportion of 60:40. Teacher educators for workshop program have duty to escort plenary one, plenary two, pretest, workshop, plenary three, independent or group work, school observation, and formative test. In this case, peer teaching is used by teacher candidate to practice teaching education planning approved by supervising teacher

\footnotetext{
* LPPMP or The Institute of Educational Development and Quality Assurance (IEDQA).
} 
educator and guru pamong (mentor teacher) from school. Although the teaching education planning that is made in workshop are different with the teaching education planning in the school because of the school's policy.

The schools that are chosen as a place for internship program meet certain standards. The standards are schools that have minimum accreditation in B level and have letter of agreement between district education office and Yogyakarta State University. The partnership is using collaborative approach. The problem that appeared was the location of the partner schools is so far away from the teacher candidate's dormitory so that the teacher candidate need a private motorcycle to do internship program. As we know that teacher candidate came from many province outboard Yogyakarta province.

The teacher educator division for field training experience has yet to use a certain standard. The assignment is based on personal choice. This matter causes some problems like the teacher educator did not meet the supervision in the field training during the 8 times the program take place. It can be minimized by applied the pattern of good personnel management described as planning, organizing, actuating and monitoring.

The monitoring covers the activities carried out within the programs of TPEP. As the process of decision-making, institutional management, management of process analytical study, etc.

\section{Controlling}

The control performed by the quality assurance team. The control needed to find out if the instructor does its job properly. The control is only done to the pattern of TPEP generally and there has not been a specific instructor.

The last stage is evaluation of TPEP implementation. One of the components in this evaluation is the evaluation of instructor PPG. The evaluation conducted at the end of the program (each $1 /$ semester). The results of this evaluation will be sent to the education minister for the improvement of the organization of the next TPEP. The evaluation is divided into two types, which are:

a. Internal Evaluation, carried out by internal evaluators, i.e. quality assurance unit.

b. External Evaluation, carried out by external evaluators, i.e. a teacher and headmaster, primary and secondary school (principal and teacher), superintendent or supervisor, and professional organizations.

The evaluation system is divided into four categories, i.e., context, input, process, and output. The result of monitoring and evaluation is used to be material consideration for the next program. The evaluation process conducted was not specific to human resource management for teacher educator in the TPEP. This led to some existing problems, which have not found solution yet, for example about schedule overlap between teaching in the TPEP and regular class.

\section{CONCLUSION}

\section{A. Conclusion}

TPEP management has been running in accordance with the principles of personnel management. Even though, there are several additional non-professional criteria that determined the assignment of teacher educator's. The other problem is the teacher educator has another responsibility for teaching regular classes that is why there are some schedules which collides with a regular schedule. Another finding, the monitoring and evaluation are only done in general that is not been specific to the teacher educator management. With the specific monitoring and evaluation, the teacher educator can fulfill the $8 x$ supervision times. That is a reason why this program needs significant improvements in order to the programs can create professional teacher.

\section{B. Suggestion}

Based on the finding as above, we propose that the university management make selection for all teacher educators who comply with the national requirements for TPEP. University management conducts specific evaluation for teacher educator performance. The spesific evaluation is needed in order to minimize the negative effect of the teacher educator management such kind of collides schedules and synchronize the schedule between regular classes and PPG schedule. So, the teacher educator management could be done effectively to improve teacher professional capacity.

\section{REFERENCES}

[1] O. Iucu, "Teacher educators-a hidden profession- a practical reflexion for administrative and law studies," Procedia-Social and Behavioral Sciences, vol. 187,2015 , pp. 668-673.

[2] Darling-Hammond, L. \& Sykes, G. (Eds.). Teaching as the learning profession: Handbook of policy and practice. San Francisco: JosseyBass A Wiley Imprint, 1999, p.12.

[3] Z. G. Kani, "Englishs language teacher educators' real world approaches to professional learning," Procedia-Social and Behavioral Sciences, vol.116, 2014, pp. 4080-4085.

[4] L. L. Hadar and D. L. Brody, "Talk about student learning: promoting professional growth among teacher educators," Teaching and Teacher Education, vol. 59, 2016, pp. 101-114.

[5] K. Juklova, "Innovations in the practical training for future czech teachers from the perspective of their educators," Procedia-Social and Behavioral Sciences, vol. 171, 2015, pp. 526-534.

[6] Lunnenberg., Dengerink., \& Korthagen, "The professional teacher educator,'Sense Publisher, Boston, p.16.

[7] Wideen, M., Mayer-Smith.,\&Moon, B. (1998). A critical analysis of the research on learning to teach: making the case for an ecological perspective on inquiry. Review of educational research. 68(2), 130-178.

[8] M. Izadinia, "Teacher educators as role models: a qualitative examination of student teachers' and teacher educators' views towards their roles," The Qualitative Report, vol. 17, 2012, pp.1-15. 
[9] C. M. Morrison, "Purpose, practice and theory: teacher educators' beliefs about professional experience," Australian Journal of Teacher Education, vol. 41, 2016, pp. 105-125.
[10] W. Nketsia, "Teacher educators' views on inclusive education and teacher preparation in ghana," International Journal of Whole Schooling, vol. 12, 2012, pp. 1-18. 